\title{
ZERO HUNGER FOR THE WORLD - BRAZIL'S GLOBAL DIFFUSION OF ITS ZERO HUNGER STRATEGY
}

\author{
Markus Fraundorfer ${ }^{1}$
}

\section{Introduction}

Brazil's ex-president Luiz Inácio Lula da Silva (2003-2010) received a number of prestigious international awards ${ }^{2}$ for his activities in the global fight against hunger and poverty, not least because of the impressive results of the Zero Hunger Strategy, launched by Lula da Silva in 2003, which achieved to considerably reduce the numbers of people living in poverty in Brazil.

A myriad of relevant actors in the global governance of food security, among them civil society organisations (CSOs) and international organisations, praised Brazil's approach to fighting hunger and poverty. In 2009, ActionAid, one of the most influential CSOs worldwide in the fight against hunger and poverty, started its global HungerFREE campaign which included the introduction of a scorecard ${ }^{3}$ with the aim to monitor the performance of developing countries in the fight against hunger. Through these monitoring practices ActionAid confirmed that Brazil's approach to fighting hunger, in the form of Lula da Silva's Zero Hunger Strategy, was the most successful one in the developing world. Brazil was ranked first by ActionAid in both 2009 and

${ }^{1}$ GIGA - German Institute of Global and Area Studies. E-mail: fraundorfer@giga-hamburg.de.

2 The most prestigious examples are the following: The FAO Agricola Medal (2005), UNESCO's Felix Houphouët-Boigny Peace Prize (2009), WFP's Global Champion in the Fight Against Hunger Award (2010) and the World Food Prize (2011).

${ }^{3}$ The indicators of the scorecard include the following factors: (1) legal commitment to the right to food, (2) investment in agriculture, (3) social protection, and (4) the performance on hunger and child nutrition (ActionAid 2009, 5). 
2010 (ActionAid 2009, 35; ActionAid 2010, 37). Oxfam's global "Grow" campaign against hunger and poverty, launched in 2011, was profoundly inspired by Lula da Silva's courageous leadership and the huge success of his Zero Hunger Strategy (Interview, 12 March 2013).

Today, the Zero Hunger Strategy is recognised as a model by the United Nations Food and Agriculture Organisation (FAO) or the World Food Programme (WFP) in the fight against hunger and poverty, and Brazil is engaged in globally diffusing the knowledge of the Zero Hunger Strategy throughout the developing world. In this article I will analyse the mechanisms which Brazil created to allow other governments and international organisations to learn from the experiences of the Zero Hunger Strategy.

At first, I will introduce the reader to the concept of nodal governance and explain how significant the creation of nodes can be for governments in exercising influence in the contemporary networks of global governance. Then, I will present four mechanisms which the Brazilian government created over the course of the last decade to spread the knowledge of its Zero Hunger Strategy. These are the International Policy Centre for Inclusive Growth, the WFP Centre of Excellence Against Hunger, the IBSA Trust Fund and the FAO-Brazil Trust Fund. I will describe these four mechanisms as essential nodes in 1) Brazil's international strategy to fight hunger and poverty and 2) the global governance of food security by arguing that Brazil has been successful in diffusing the knowledge of its Zero Hunger Strategy through nodal governance.

\section{The concept of nodal governance}

Burris et al present the concept of nodal governance as an "elaboration of contemporary network theory" (Burris et al. 2005, 33). In global governance today, networks are more important than ever for governments to exercise influence. Ikenberry and Wright (2008) emphasise the fact that the "networked" condition of global governance and "[t]he complexity and multifaceted features of this open and institutionalized system provide multiple access points and pathways for integration" $(2008,11)$. This is why I will turn my attention to nodes as the most important components of these global networks. In the same vein, Castells underlined that "[a] network has no center, just nodes" $(2004,3)$ and specified: 


\section{Markus Fraundorfer}

"Nodes may be of varying relevance for the network. Nodes increase their importance for the network by absorbing more relevant information, and processing it more efficiently. The relative importance of a node does not stem from its specific features but from its ability to contribute to the network's goals." (Castells 2004, 3)

In this context, Hein, Burris and Shearing (2009) present the concept of nodal governance as a useful conceptual model, which "provides a framework for characterizing the distribution of power in dynamic systems of polycentric governance" $(2009,82)$. Nodes are sites within global governance which share the following four characteristics (Burris et al. 2005, 37-38):

- A way of thinking (mentalities) about the matters that the node has emerged to govern;

- A set of methods (technologies) for exerting influence over the course of events at issue;

- Resources to support the operation of the node and the exertion of influence; and

- A structure that enables the directed mobilization of resources, mentalities and technologies over time (institutions).

When bringing together different networks, the overall performance of a node may vary, depending on the number of actors which dispose of a specific amount of resources in order to engage in creating an institutional framework $(2005,38)$. In the same vein, several nodes together can establish a network which may result in the establishment of other (super-structural) nodes even stronger in exercising influence due to more resources and a stronger institutional framework at hand $(2005,38-39)$. In this sense, nodes vary in institutional strength, resources, methods and mentalities depending on the actions of their actors and the linkages with other nodes or networks $(2005,39)$.

Castells sums up the aspect of power involved in nodal co-ordination by emphasising that "a node is able to concentrate power in form of resources, discourses, institutions and methods which then may be used by one or more actors to achieve specific outcomes or to restrain other actors from achieving specific outcomes" (Castells 2004, 3). 


\section{Brazil's nodal creation efforts in the global fight against hunger and poverty}

\section{1) The International Policy Centre for Inclusive Growth (IPC-IG)}

First steps of an international research centre on studying poverty

The Centre was officially launched in 2002 as the International Poverty Centre (IPC) in Rio de Janeiro - moved to Brasília in 2004 - and became the very first UN body with a global mandate on Brazilian soil as the result of a partnership between the Brazilian government and UNDP (MRE 2002; IPC-IG website).

The partnership was focused on a cooperation agreement between UNDP and IPEA (Brazilian Institute of Applied Economic Research), a think tank of the Brazilian government internationally recognised for its scientific studies on poverty and inequality (MRE 2002). As a consequence, the main objective of the Centre consisted in evaluating policies to fight poverty, establishing national poverty lines and finding ways of how to measure growth (Interview, 27 February 2013). The Centre's main task was purely technical in nature by providing scientific research and establishing knowledge networks on various ways of measuring poverty and growth (MRE 2002; Interview, 27 February 2013).

Three years later, however, the significance of the Centre changed with a research project, funded by the UK's Department for International Development (DFID), on the impact of the Bolsa Familia programme on poverty and inequality in Brazil (IPC-IG 2008). One of the Centre's representatives involved in this study ${ }^{4}$ emphasised that the scientific evidence of the success of Bolsa Familia on reducing poverty and inequality attracted the attention of several international organisations including the World Bank, which at the beginning was critical of Bolsa Familia (Interview, 27 February 2013). The impressive scientific results led to a boost in the international recognition of the Centre and Brazil's Bolsa Familia programme which started a

${ }^{4}$ See a summary of the study published in 2007: Veras Soares, Fábio, Perez Ribas, Rafael and Guerreiro Osório, Rafael (2007), "Evaluating the Impact of Brazil's Bolsa Familia: Cash Transfer Programmes in

Comparative Perspective", IPC Evaluation Note 1, available at: http://www.ipcundp.org/pub/IPCEvaluationNote1.pdf (accessed 28 February 2013). 
process of involving the Centre in efforts to transfer the knowledge of Bolsa Família to other countries in Africa, exemplified by the Brazil-Africa Cooperation Programme on Social Development.

The Africa-Brazil Co-operation Programme on Social Development was officially launched in 2008 involving the Centre, the Brazilian Ministry of Development and Fight against Hunger (MDS) and the UK's DFID. The whole programme had evolved out of a former partnership between the MDS and the DFID aimed at familiarising six African countries (Ghana, Guinea Bissau, Mozambique, Nigeria, South Africa and Zambia) with Brazil's Bolsa Familia Programme (MDS 2008; IPC-IG 2008). When in this process the partnership helped Ghana to develop an own cash-transfer programme modelled on Brazil's Bolsa Familia programme the partnership was extended to become the AfricaBrazil Co-operation Programme to meet the demand from other African countries in developing cash-transfer programmes (IPC 2008).

The whole programme focused on the benefits of knowledge-sharing complemented by technical co-operation through the participation of Brazilian government representatives in regional experts meetings in Africa ${ }^{5}$, study tours to Brazil for African government representatives and distance-learning efforts to further familiarise the participating African countries with Brazil's experience in its Zero Hunger Strategy, in particular social protection schemes and cash-transfer programmes (MDS 2008; IPC-IG 2008).

\section{The expansion of the Centre's responsibilities - South-South Learning}

So far, the Centre's activities had merely been focused on low and middle-income countries from the developing world, Africa in particular. The new reputation of the Centre based on its own research strength, attracted the attention of the Brazilian government which, in 2009, signed a second Memorandum of Understanding with UNDP further expanding the responsibilities of the Centre. With its original name changed from International Poverty Centre (IPC) to International Policy Centre for Inclusive

5 The Centre was responsible for organising the participation of Brazilian government officials in the regional experts meetings (Interview, 27 February 2013). 
Growth (IPC-IG) the new Memorandum of Understanding envisaged further developing the institutional structure of the Centre, expanding its topics and strengthening South-South learning, in particular with the other big emerging economies India, Russia and China (MoU 2009; Interview, 27 February 2013).

The actors linked to the Brazilian government include the Brazilian Institute of Applied Economic Research (IPEA), the Secretariat of Strategic Affairs at the Presidency of the Republic (SAE) and the Ministry of Foreign Affairs (MRE). At UNDP, the Poverty Group of UNDP's Bureau for Development Policy is responsible for the collaboration with the Brazilian institutions. ${ }^{6}$

In the area of South-South co-operation the Centre established an online collaborative platform called the South-South Learning on Social Protection Gateway to further facilitate policy dialogue and knowledge-sharing activities. $^{7}$ This gateway links the Centre to a further group of partners including research centres, UN agencies, development agencies and communications platforms. ${ }^{8}$ In addition, the Centre built connections with the other emerging economies through the IBSA-Dialogue and the BRIC(S) summit $^{9}$. In the context of IBSA, the Centre is closely linked to the IBSA Dialogue Forum where it is responsible for the organisation of the IBSA Academic Forum in Brazil, a special platform engaged in the exchange of knowledge and ideas between academics and scholars from the three participating countries India, Brazil and South Africa (IPC-IG 2010). The Centre organised the IBSA Academic Forum in 2010, when the IBSA Summit took place in Brasília (IPC-IG 2010). When the BRIC summit took place in Brasília in the same year, the Centre organised the BRIC think tank seminar ${ }^{10}$,

${ }^{6}$ See the website of IPC-IG, available at: http://www.ipc-undp.org/pages/newsite/menu/about/introduction.jsp?active $=0$ (accessed 24 February 2013).

${ }^{7}$ See http://south-south.ipc-undp.org/about-us (accessed 24 February 2013).

${ }^{8}$ See http://south-south.ipc-undp.org/partners. (accessed 24 February 2013).

9 When the last summit took place in Brazil it was still known as the BRIC-summit excluding South Africa. Only in 2011, South Africa officially joined the Summit making it the BRICS-summit.

${ }^{10}$ Each of the BRIC countries nominates one of its think tanks to organise the think tanks seminar as part of the BRIC summit. The Brazilian government nominated IPEA, and as such IPC-IG, as the responsible think tank for organising the seminar during the BRIC summit in Brazil (Interview, 27 February 2013). 


\section{Markus Fraundorfer}

a platform for knowledge-exchange among think tanks and scientists from the BRIC countries (CCTV 2010). ${ }^{11}$ Over the last few years, the Centre has also been a partner of the institutional mechanism of the G20 developing countries, contributing with its research expertise on social protection and inclusive growth to the G20 development working groups (IPC-IG 2012a: 9).

\section{The IPC-IG as a leading research centre on social policy in the global south}

As emphasised in 2012 by then director Rathin Roy, the Centre aims to be the "leading thought centre on social policy related to the Global South" (IPC-IG 2012b: 7). The international success of the Centre began with its own research on the impact of the Bolsa Família programme, which turned the Centre into an international point of reference for knowledge-sharing on this programme (Interview, 27 February 2013).

By engaging in knowledge-sharing activities with African, Latin American and Asian countries, the Centre was able to familiarise low and middle-income countries from the developing world with Brazil's success story of Bolsa Famíla. In this process, the Centre build up a strong research expertise and a global network on social protection and cash-transfer schemes with universities, research institutes, national governments, the Brazilian and international media, regional organisations in Africa such as the African Union and international organisations and agencies via its digital South-South Learning on Social Protection Gateway (IPC-IG 2012a; 2012b).

From 2009 onwards, the Centre has further extended this network through its involvement in the IBSA Academic Forum, the BRIC think-tank seminar and the G20 development working groups. Relying on its general function as a platform for knowledge-sharing on social protection schemes and cash-transfer programmes, and in this context the global dissemination of the success of Brazil's Bolsa Familia programme, the Centre has turned into an important instrument in Brazil's global fight against hunger and poverty, as one representative emphasised:

11 At that seminar, topics discussed included the role of the BRIC countries in global governance institutions, climate change and international trade (Portal Brasil 2010). 
"We [the Centre] have been one of the elements. I wouldn't claim to be the most important one, but we have worked [...] on a level of reaching people who would be less willing to buy the discourse if it had not been based on strong and robust academic research. So I think that is what makes IPC [the International Policy Centre] different from the others [institutes]. But at the same time, because we do this type of work, it makes us less visible for the politicians and for big politics." (Interview, 27 February 2012)

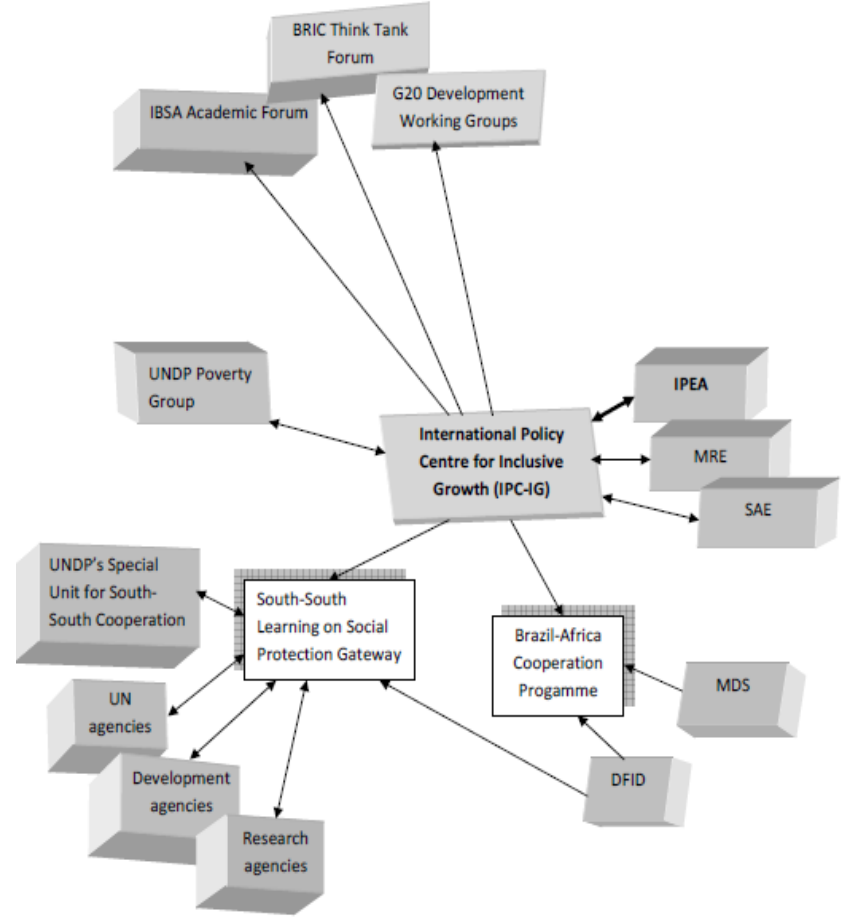

Figure 1: The International Policy Centre for Inclusive Growth (IPC-IG)

The figure shows that the IPC has evolved into an international mechanism which established important links with several global governance mechanisms relevant for Brazil's international hunger and poverty strategy. Ironically, the Brazilian government (in form of the Ministry of Foreign Affairs) did not use the Centre as an instrument in strengthening or legitimising the government's official discourse when the Centre was established. Only when the Centre became influential on its own as a research centre sought out by several 


\section{Markus Fraundorfer}

African and Latin American countries, did the government start to incorporate it in its international hunger and poverty strategy, renewing the cooperation agreement in 2009 and directing the research focus, apart from low and middleincome countries from the developing world, toward the other BRIC-countries.

\section{2) The WFP Centre of Excellence against Hunger}

\section{The role of Brazil's National Fund for the Development of Education (FNDE)}

The WFP Centre of Excellence was officially launched in November 2011 in Brasília following a co-operation agreement between the Brazilian government and the World Food Programme (WFP) (WFP 2013, 6). The Centre seeks to become a global reference point and knowledge platform on school feeding, nutrition and food security.

The current director of the Centre, Daniel Balaban, belonged to the key formulators of Brazil's Zero Hunger Strategy with Brazil's National Fund for the Development of Education $(\mathrm{FNDE})^{12}$ being responsible for the implementation of the School Feeding Programme (Interview, 01 March 2013). The main impetus for the establishment of the Centre originated from Balaban's experience as FNDE`s president (2006-2011) and the successful implementation of the school feeding programme in Brazilian schools (Interview, 01 March 2013; FNDE 2012):

WFP's then executive-director Josette Sheeran embraced Balaban's idea and suggested he become president of the Centre due to his own experience at the heart of implementing Brazil's Zero Hunger Strategy (Interview, 01 March 2013). Josette Sheeran emphasised that the Centre was established in Brasília to benefit from Brazil's unique experiences and success as a global champion in the fight against hunger and poverty:

"As a world champion in the fight against hunger, Brazil has a wealth of experience that can be shared with governments eager to learn how they achieved that success

12 FNDE is an autonomous agency linked to the Ministry of Education with the responsibility to improve the infrastructure of Brazil's education system. In this context, improving the quality of school meals is one of its manifold tasks. 
and adapt it to their own countries" [...] "The Centre of Excellence will provide a unique South-South bridge to ending hunger. Brazil has taken the fight against hunger and malnutrition seriously and is now among those defeating hunger faster than any nation on earth. We will partner to leverage this success to other nations seeking to end hunger and malnutrition." (WFP 2011)

\section{The Centre's involvement in the developing world}

Since the establishment of the Centre in late 2011, the focus has been on knowledge-sharing of the components of Brazil's successful school-feeding programme. So far, eighteen countries ${ }^{13}$ from all continents of the developing world have asked for advice from the Centre with many other countries in a long waiting line ${ }^{14}$ (Interview, 01 March 2013; WFP 2013). The Centre organises a two-week high-level meeting with members from the government of the interested country in Brasília. In the first week these members are exposed to representatives of the Ministry of Foreign Affairs and the Ministries involved in Brazil's school feeding programme such as the Ministry of Agriculture, the Ministry of Social Development and Fight Against Hunger, the Ministry of Agrarian Development or the Ministry of Education. In the second week, the foreign officials are invited for a field-visit to talk to those actors directly involved in the Brazilian experience on the ground including small holders and representatives from the municipalities (Interview, 01 March 2013).

After these two weeks, the Centre invites the foreign mission to draft a Plan of Action including all those elements that they consider as relevant for their particular social context in their country. Balaban stressed that the Centre did not see itself in the position of pressuring anyone into accepting or copying Brazil's national success story even if the worldwide fascination with this success story might give the Centre the power to do so (Interview, 01 March 2013). For Balaban, the only conditionality on which the Centre accepts applications refers to the high involvement and clear engagement of the highest political levels of the country (Interview, 01 March 2013).

13 East-Timor, Guinea-Bissau, Haiti, Kenya, Malawi, Mali, Mozambique, Tanzania, Ghana, Laos, Rwanda, Senegal, Togo, Zambia, Bangladesh, Ivory Coast, Nigeria, and Zimbabwe (WFP 2013).

14 Among them countries like Bangladesh, Nepal, Tadzhikistan, Sri Lanka, the Philippines or Burkina Faso (Balaban 2012). 


\section{Markus Fraundorfer}

When the missions return to their respective countries, they submit the Action Plan to further discussions and adapt it according to their own needs. In the ensuing implementation process, the Centre provides further assistance via the respective WFP country office and Brazilian technical consultants from Brazilian universities and research institutes which serve as the Centre's local focal points on the ground (Interview, 01 March 2013). Apart from low and middle-income countries from Africa, Asia and the Caribbean involved so far, the Centre has also been cultivating brainstorming sessions and policy dialogue with the other continental emerging powers China, India and Russia.

Since 2012, the Centre has been involved in setting up a much more ambitious programme called Purchase from Africans for Africa (PAA) Programme which is based on Brazil's Food Acquisition Programme, another component of the Zero Hunger Strategy. In this programme the Centre aims to promote local food purchase and family agriculture in ten African countries to strengthen family agriculture and small holders in these countries (Souza and Klug 2012: 16). Five African countries - Ethiopia, Malawi, Mozambique, Niger and Senegal - will benefit from humanitarian assistance, while a further five countries - Ghana, Rwanda, Zimbabwe, Kenya, Ivory Coast - will receive technical assistance. The Centre will function as the main coordinator of the new programme involving the Brazilian Agency for Technical Cooperation (ABC) and the department of the Ministry of Foreign Affairs responsible for humanitarian assistance (CGFome) in cooperation with the FAO and WFP's Purchase for Progress Programme (P4P) ${ }^{15}$ (Souza and Klug 2012, 16).

Balaban underlined that, as in the case of Brazil's own Zero Hunger Strategy, both programmes were closely interrelated and supposed to complement each other. The rationale lay in promoting family agriculture to strengthen the capacity of small holders to produce the agricultural products for the school meals (Interview, 01 March 2013).

15 WFP's P4P Programme, launched in 2008, consists of a diverse network of partnerships in 21 countries in Africa, Asia and Latin America aimed at strengthening family agriculture (Souza and Klug 2012, 17). 
The WFP Centre of Excellence Against Hunger as a new global governance mechanism

Due to the assistance provided by the Centre several African countries Mozambique, Malawi, Mali and Rwanda - are already in the process of implementing school feeding programmes based on the Brazilian experience (WFP 2013, 16). The Centre has already established close links with key international organisations in the global governance of food security and, apart from being a crucial gateway node in Brazil's global fight against hunger and poverty the Centre is also on its way to becoming a significant global governance mechanism in food security.

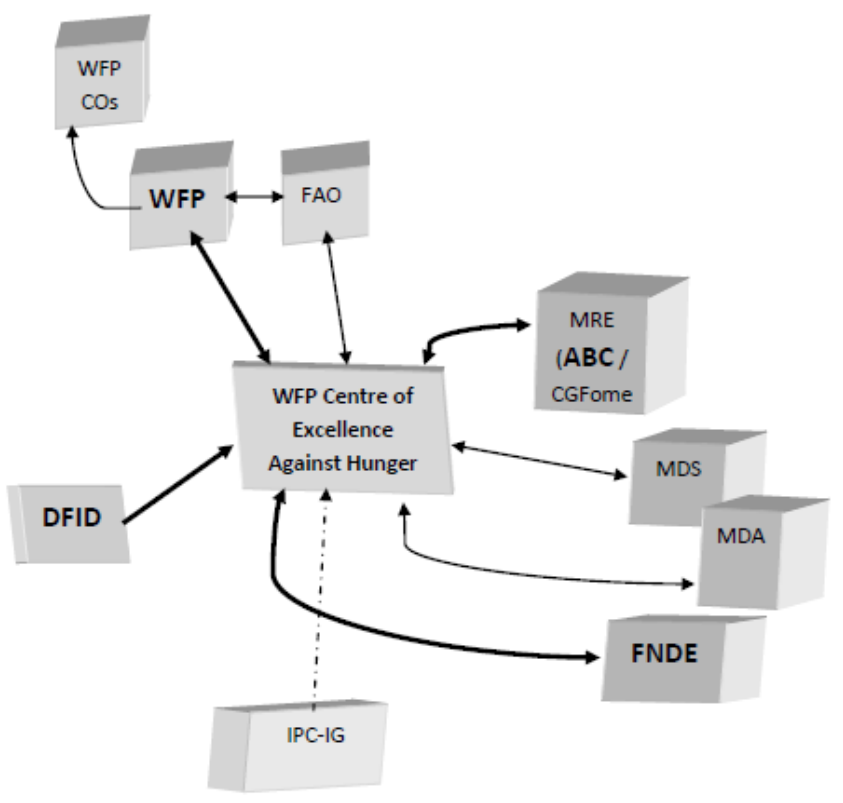

Figure 2:16 The WFP Centre of Excellence Against Hunger

The key partners $(\longleftrightarrow)$ of the WFP Centre of Excellence are WFP with its Country Offices (WFP COs), the UK's DFID and on the Brazilian side

${ }^{16}$ Based on WFP 2013. 
FNDE and ABC. Depending on the Centre's projects, other partners $(\longleftrightarrow)$ are involved such as the FAO or other Brazilian ministries and agencies of which the most relevant ones are the Ministry of Social Development and Fight Against Hunger (MDS), the Ministry of Agrarian Development (MDA) and the Department of the Ministry of Foreign Affairs responsible for humanitarian assistance (CGFome).

Its mission and rationale is fully based on Brazil's successful Zero Hunger Strategy, which made the Centre not only possible at the outset but also attractive to developing countries all over the world as a global platform to learn about the school-feeding programme and the food acquisition programme. Balaban put it in the following words:

"I think that this consolidated idea [Zero Hunger Strategy] created a merchandising with the result that Brazil became the centre [of attraction], not least because of the results] [...]. When they [other governments] look at the results, they want to understand the public policies behind." (Interview, 01 March $2013)^{17}$

And here, Balaban indirectly stressed the important role of the IPC-IG which in the first place published the successful results of the Zero Hunger Strategy and made the world aware of this impressive success story. Today, it is also the IPC-IG which publishes the possible impact and results of the programmes carried out by the WFP Centre. ${ }^{18}$ Even though no official relationship exists between these two Centres in Brasília, the WFP Centre may take advantage of the IPC-IG as an outlet for research-based publications on the development and success of its programmes and promote itself among the partners of the IPC-IG in the world $(-\cdots \cdot)$

\section{3) The IBSA Trust Fund for the Alleviation of Poverty and Hunger}

The IBSA Trust Fund was launched in 2004 following Lula da Silva's

\footnotetext{
${ }^{17}$ Translation from the Portuguese by the author.

${ }^{18}$ IPC-IG published a first analysis of the launch of the PAA Programme in 2012 in its key publication Poverty in Focus and is about to publish further analyses of the development of this programme in 2013 (Interview, 26 February 2013).
} 
announcement at the 58 ${ }^{\text {th }}$ UN General Assembly Session in September 2003 to create a global fund to fight hunger and poverty (ABC 2012). The Fund emerged out of the IBSA Dialogue Forum, a South-South co-operation mechanism amongst the three countries, established in 2003 through the Brasília Declaration (IBSA 2010). The Fund ${ }^{19}$ unites India, Brazil and South Africa to reinforce the fight against hunger and poverty in the developing world and strengthen South-South co-operation in the areas of development.

Since the Fund is officially administered by UNDP, its institutional framework is located at the UN in New York. UNDP's Special Unit for SouthSouth Co-operation acts both as the fund manager and as the board of director's secretariat. The Board of Directors, comprised of the respective UN ambassador of the three countries, acts as the Fund's executive body responsible for the strategic direction of the selected projects.

The Fund was regarded as so successful that it received the UN SouthSouth Partnership Award in 2006 and the Millennium Development Goals Award for having significantly contributed to South-South co-operation and the Millennium Development Goals (IBSA 2010; MRE 2010). So far, 15 projects have been accepted by the Fund on a demand-driven basis of which 5 have already been completed, four recently approved and a further six are still ongoing (IBSA 2011). ${ }^{20}$ The trust fund confronts hunger and poverty by having accepted local projects in a variety of thematic areas with agriculture, waste management and health care as the most important areas. Most of the projects are located in Africa (45.4\%) and Latin America (22.3\%), while the focus lies particularly on the least developed countries $(73.7 \%)($ IBSA 2011, 5)

\section{4) The FAO-Brazil Trust Fund}

In 2005, Lula da Silva together with the heads of state and government of the Central American Integration System (Sistema de la Integración Centroamericana - SICA) agreed to propose to the UN in New York and the FAO in Rome the launch of an initiative for a Latin America without hunger (SICA 2005). The FAO Regional Office for Latin America and the Caribbean

\footnotetext{
${ }^{19}$ See the official website at http://tcde2.undp.org/IBSA/about/about.htm (accessed 19 March 2013).

${ }^{20}$ For a detailed overview of the projects see IBSA 2011.
} 
assumed the coordinating role of the initiative which has as its aim the eradication of hunger in Latin America and the Caribbean by 2025.21 This general objective is pursued by concentrating on capacity-building measures, raising the profile of the fight against hunger and the right to food on the agenda of governments and international organisations at national, regional and global levels, and monitoring the state of food security in Latin American countries supported by national governments, actors from the private sector and civil society (FAO 2007, 2).

In order to carry out the objectives set in the agenda of the initiative the FAO together with the Brazilian government - represented by the Ministry of Agrarian Development (MDA), the Ministry of External Relations (MRE), the Ministry of Fisheries and Agriculture (MPA) and the National School Development Fund (FNDE) - launched the FAO-Brazil Trust Fund in 2008, coordinated by the FAO Regional Office for Latin America and the Caribbean (Marco Estratégico n.d.).

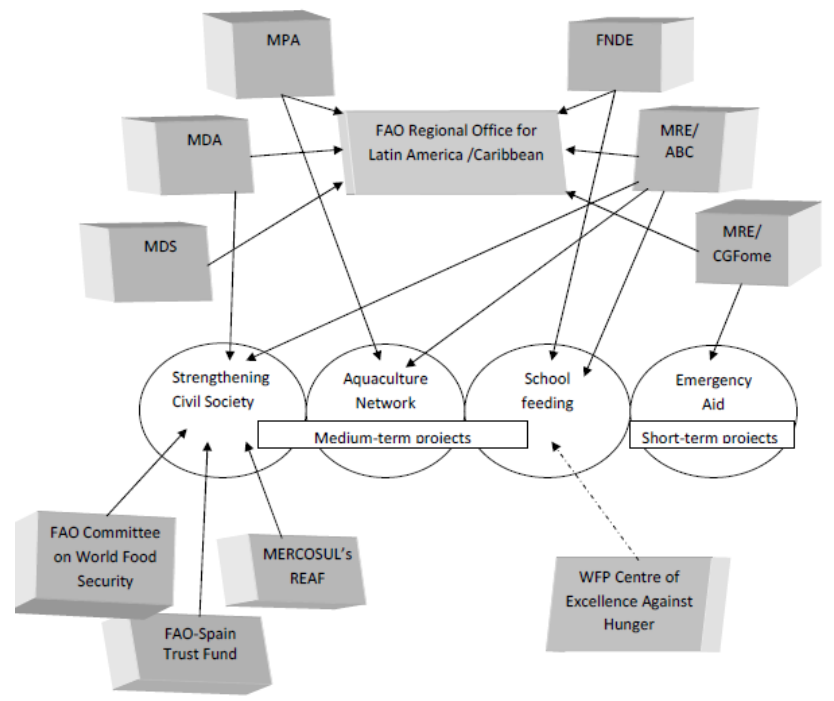

Figure 3: The Brazil-FAO Trust Fund ${ }^{22}$

\footnotetext{
${ }^{21}$ For more information see http://www.rlc.fao.org/proyectoiniciativa/iniciativa.htm (accessed 05 March 2013).

${ }^{22}$ Model developed with the help of the official website of the Brazil-FAO Cooperation Programme, available at: http://www.rlc.fao.org/es/programabrasilfao/ (accessed 05 March 2013).
} 
The whole fund is co-ordinated through the FAO Regional Office for Latin America and the Caribbean in Santiago de Chile supported by a technical team of consultants and coordinators from the participating Brazilian Ministries (Marco Estratégico n.d., 6/7). The FAO Regional Office also receives support from the FAO Sub-regional Office for Central America in Panama as far as projects are concerned which are implemented in Central American countries and from the Liaison Officer for Brazil and Latin America at the FAO Headquarters in Rome (Marco Estratégico n.d., 7).

The projects of the fund are implemented in the four main areas of humanitarian assistance/emergency aid, school feeding, strengthening civil society, and strengthening / consolidating the aquaculture network in the Americas. Brazilian representatives from the participating Ministries (MDS, MDA, MPA) and agencies/departments (FNDE, ABC, CGFome) support both the FAO Regional Office and the implementation process of the projects. While representatives from the MRE/CGFome contribute to the short-term projects in emergency aid, representatives from the MPA (Ministry of Fishing and Agriculture) support projects on strengthening the Aquaculture Network in the Americas and representatives from the MDA (Ministry of Agrarian Development) support projects involving the strengthening of civil society. The projects in the areas of school feeding, strengthening civil society and Aquaculture are further supported financially by $\mathrm{ABC}$, while the FNDE contributes with financial resources to the realisation of school feeding projects. Through the implementation of the projects the Brazilian representatives are further supported by the FAO representatives in the respective countries, officials from local governments, NGOs and regional organisations. Short-term projects of a humanitarian dimension have been carried out in several countries in Africa and Latin America and the Caribbean, while the medium-term projects have been concentrating on capacity-building, knowledge-sharing and policy-dialogue in Latin-American countries ${ }^{23}$.

In 2009, the FAO established the initiative for a Latin America without hunger as the strategic framework for all the projects financed by the FAO in

23 For a detailed account of these projects see http:/www.rlc.fao.org/es/programabrasilfao/proyectos/ (accessed 04 May 2013). 


\section{Markus Fraundorfer}

Latin America in the combat against hunger and poverty, linking the BrazilFAO Trust Fund to the Spain-FAO Trust Fund, created in 2006 between Spain and the FAO in the area of food security, family agriculture and rural development. ${ }^{24}$ In this sense, the initiative, called into life by Lula da Silva, turned into a bridge between the Brazil-FAO Trust Fund and other important actors and bodies in the FAO reinforcing the commitment demanded by Lula da Silva and Brazil's active role in the global fight against hunger and poverty.

In the projects on strengthening the dialogue among FAO, governments and civil society in Latin America ${ }^{25}$, Brazil is involved through its Ministry of Agrarian Development (MDA). Due to the importance of the issue to the civil society actors in the FAO Committee on World Food Security, the programme is linked to the agenda of the FAO Committee. The FAO-Spain Trust Fund is involved in contributing to capacity-building efforts of rural civil society organisations and in assisting in establishing public policies in family agriculture. The programme also cooperates with Mercosul's REAF (Reunião Espezializada sobre Agricultura Familiar do Mercosul) ${ }^{26}$, the Special Meeting on Family Agriculture of Mercosul's member countries.

The school-feeding programme for Latin American countries ${ }^{27}$ has been heavily supported by FNDE and its then director Daniel Balaban. By involving all government actors from the highest level and a wide range of actors from the society (CSOs, research institutions, professors, educators, etc.) of the benefiting country the programme aims to share Brazil's knowledge and build a knowledge and information network.

\footnotetext{
${ }^{24}$ For more information on the Trust Fund between Spain and the FAO see http://www.rlc.fao.org/fondo/ (accessed 04 May 2012).

25 Benefiting countries are Argentina, Uruguay, Paraguay, Chile, Bolivia, Peru, Colombia, Ecuador, El Salvador, Guatemala, Honduras, Nicaragua, Costa Rica and the Dominican Republic (FAO 2012a).

26 REAF was launched in 2004 by Brazil's Ministries of Foreign Affairs and Agrarian Development to serve the member states of Mercosul as a platform to further strengthen family agriculture in the Mercosul area. As one of the most recent results of these special meetings, the Mercosul countries established a fund in 2008 to finance projects and programmes on family agriculture. Within the framework of this fund Mercosul member states started a co-operation programme with FAO in early 2013 with the aim to further promote public policies on family agriculture in the Mercosul area (FAO 2013; MRE 2008; REAF 2008a and 2008b).

${ }_{27}$ Benefiting countries are Bolivia, Colombia, El Salvador, Guatemala, Honduras, Nicaragua, Paraguay, Peru and the Dominican Republic (FAO 2012b).
} 
The WFP Centre of Excellence Against Hunger so far has no official relationship with the FAO-Brazil Programme. However, since the WFP Centre is automatically consulted by the Ministry of Foreign Affairs in all of Brazil's relations with other countries on school-feeding programmes (Interview, 01 March 2013), it contributes with its expertise to the school-feeding projects carried out under the umbrella of the FAO-Brazil Cooperation programme $(-\cdots \cdot)$.

In the third area, emergency aid, the department of the Brazilian Ministry of Foreign Affairs CGFome has been actively involved in providing humanitarian assistance to countries in Latin America and the Caribbean and Africa $^{28}$ by contributing to the reconstruction of infrastructure (schools, hospitals, community centres, etc.) affected by catastrophes or cooperating for the purchase of food, water and other basic needs.

In the fourth area, Brazil's Ministry of Fishing and Agriculture (MPA) is engaged in contributing to the consolidation of an aquaculture network of the Americas. Apart from these four core areas, new Brazilian initiatives have resulted in further cooperation programmes with the FAO.

In a visit to Brasília in late 2012, the current FAO regional representative of Latin America and the Caribbean, Raúl Benitez, emphasised that the key rationale of the cooperation between the FAO and Brazil lay in sharing Brazil's successful experience in fighting hunger and poverty to help further develop other countries in Latin America and the Caribbean (FAO 2012d). Neither Brazil nor the FAO, however, have the intention to simply copy Brazil's model. Hélder Muteia, the FAO representative to Brazil between 2010 and 2012, emphasised that the FAO aimed to learn from Brazil's experiences in order to adapt the different components of the Zero Hunger Strategy to realities which are very different from the Brazilian one (Savanachi 2010).

28 Guatemala, Chile, Haiti, Congo, Mozambique, Guinea-Bissau, Angola, Paraguay, Bolivia and Nicaragua (FAO 2012c). 


\section{Markus Fraundorfer}

\section{Conclusion}

Brazil has engaged in the global fight against hunger and poverty by building four key nodes in partnership with several international organisations (UNDP, WFP and FAO). On the one hand, the Brazilian government launched two Centres which have globally diffused Brazil's knowledge on different planes.

The International Policy Centre for Inclusive Growth in its capacity as a research centre on poverty made other countries and organisations aware of the impressive results of various programmes of Brazil's Zero Hunger Strategy and contributed to legitimising this model based on serious and competent research. The IPC-IG has established a vast network in the developing world with national governments, research institutions and regional and international organisations.

The WFP Centre of Excellence Against Hunger represents a node that focuses on spreading the knowledge of specific programmes of the Zero Hunger Strategy which are by now the School Feeding Programme and the Food Acquisition Programme. Together with FAO, WFP and other donor institutions the Centre sees its differential in the area of technical cooperation efforts by directly engaging governments from developing countries with these programmes and helping to launch similar programmes in the respective countries. In addition, the WFP Centre in not only an important node for Brazil, but an essential node in the global governance mechanisms of food security, on its way to becoming a worldwide point of reference for long-lasting solutions and successfully tested public policies in the fight against hunger.

On the other hand, Brazil created two funds which concentrate a considerable amount of resources to engage in technical cooperation efforts based on the programmes and the rationale of Brazil's Zero Hunger Strategy. The IBSA Trust Fund concentrates the financial and institutional resources of UNDP, Brazil, India and South Africa, while the FAO Trust Fund combines Brazil's knowledge with the institutional infrastructure of FAO. Both funds diffuse Brazil's knowledge through specific short and long-term projects in the developing world, in particular in Latin America and Africa.

All four nodes share a particular way of thinking based on the transfer of knowledge in relation to the Zero Hunger Strategy. They concentrate a specific set of methods and technologies all based on Brazil's successful 
experiences in its national fight against hunger and poverty. They concentrate the financial resources of Brazil and other actors in the global governance of food security committed to eradicating poverty and hunger. And they rely on an institutional framework - a research centre, a centre of excellence against hunger and two funds - which allows these nodes to spread the Zero Hunger Strategy throughout the world. Along with these four key characteristics, all the four nodes represent partnerships between Brazil and international organisations which facilitates a profound and quick integration into the global governance mechanisms of food security. 


\section{Markus Fraundorfer}

\section{REFERENCES}

Interview with one representative from the International Policy Centre for Inclusive Growth, February 27, 2013, Brasília.

Interview with Daniel Balaban, March 01, 2013. Brasília.

Interview with one representative from Oxfam Brazil, March 12, 2013. Brasília.

ABC. 2012. "Cooperação Sul-Sul: IBAS", Available at: http://sv51.dna.com.br/abc/webforms/interna.aspx?secao_id=86 Accessed 03 May, 2013.

ActionAid. 2009. "Who's really fighting hunger? ActionAid's HungerFREE scorecard investigates why a billion people are hungry". Available at: http://www.scribd.com/doc/22625152/Hunger-Free-Scorecard-

Actionaid-2009-1. Accessed September 02, 2011.

2010. "Who's really fighting hunger? Why the world is going backwards on the goal to halve hunger and what can be done". Available at:

http://www.actionaid.org/sites/files/actionaid/actionaid-scorecardreport-2010.pdf. Accessed September 02, 2011.

Balaban, Daniel. 2012. "Centro de Excelência contra el Hambre". Available at: http://www.rlc.fao.org/fileadmin/templates/fondobrasil/documentos/F oro_expertos/Apresentaciones/PMA-

Brasil_Centro_de_Excelencia_Contra_El_Hambre_-_11-09-2012.pdf. Accessed March 04, 2013.

Burris, Scott; Drahos, Peter; and Clifford Shearing. 2005. "Nodal Governance", Australian Journal of Legal Philosophy 30: 30-58.

Castells, Manuel (ed.). 2004. The Network Society: A Cross-cultural Perspective, Northampton: Edward Elgar.

CCTV. 2010. "BRIC-think tank seminar begins in Brasilia", 15 de abril. Available at:

http://www.ipc-undp.org/pressroom/pdf/IPCPressroom306.pdf.

Accessed February 28, 2013.

FAO. 2007. "Plan de Acción. Iniciativa América Latina y Caribe sin Hambre", Available at:

http://www.rlc.fao.org/proyectoiniciativa/pdf/planaccion.pdf.

Accessed March 06, 2013.

2010. "Brasil y FAO apoyan el fortalecimiento de Fondos de alimentación escolar en América Latina", November 18. Available at: http://www.rlc.fao.org/pt/programabrasilfao/sala-de- 
imprensa/noticias/apoyo-fortalecimiento-fondos-alimentacion-escolaralc/. Accessed March 04, 2013.

2012a. "Programa de Cooperação Internacional Brasil-FAO: Fortalecimento do Diálogo entre FAO, Governos e Sociedade Civil". Available at:

http://www.rlc.fao.org/pt/programabrasilfao/projetos/fortalecimentoda-sociedade-civil/. Accessed March 05, 2013.

2012b. "Programa de Cooperação Internacional Brasil-FAO: Fortalecimento dos programas de alimentação escolar no âmbito da Iniciativa América Latina e Caribe Sem Fome 2025". Available at: http://www.rlc.fao.org/pt/programabrasilfao/projetos/alimentacaoescolar/. Accessed March 05, 2013.

- 2012c. "Programa de Cooperação Internacional Brasil-FAO: Cooperação Humanitária da Republica Federativa do Brasil". Available at:

http://www.rlc.fao.org/pt/programabrasilfao/projetos/cooperacaohumanitaria/. Accessed March 05, 2013.

. 2012f. "FAO: experiência brasileira na Cooperação Sul-Sul é estratégica na luta contra a fome na América Latina e Caribe", October 29. Available at: http:/www.rlc.fao.org/pt/programabrasilfao/sala-deimprensa/noticias/fao-experiencia-brasileira-na-cooperacao-sul-sul-eestrategica-na-luta-contra-a-fome-na-america-latina-e-caribe/.

Accessed March 05, 2013.

. 2013. "Mercosur y FAO crean nueva alianza para apoyar a la agricultura familiar", 28 de fevereiro. Available at: http://www.rlc.fao.org/en/press/news/mercosur-y-fao-crean-nuevaalianza-para-apoyar-a-la-agricultura-familiar/. Accessed March 05, 2013.

FNDE. 2012. "Presidentes". Available at: http://www.fnde.gov.br/fnde/institucional/quem-somos/presidentes. Accessed March 05, 2013.

Hein, Wolfgang; Burris, Scott; and Clifford Shearing. 2009. "Conceptual Models for Global Health Governance". In Making Sense of Global Health Governance. A Policy Perspective, edited by Kent Buse, Wolfgang Hein e Nick Drager. New York: Palgrave MacMillan.

IBSA Trust Fund. Official Website. Available at: http://tcdc2.undp.org/IBSA/about/about.htm. Accessed May 03, 2012. IBSA. 2010. "The IBSA Fund", January 13. Available at: http://www.ibsatrilateral.org/index.php?option=com_content\&view $=$ article\&id $=29 \& I$ temid=79. Accessed May 03, 2012. 
. 2011. "2011 Annual Report. Project Portfolio Overview". Available at: http://tcdc2.undp.org/ibsa/Upload/IBSAReport.pdf. Accessed March 19, 2013.

Ikenberry, John; and Thomas Wright. 2008. Rising Powers and Global Institutions, New York: The Century Foundation.

IPC-IG. Official Website. Available at: http://www.ipc-undp.org/. Accessed March 05, 2013.

IPC-IG. 2008. "Africa-Brazil Cooperation Programme on Social Development", Available at: http://www.ipc-undp.org/ipc/PageAfricaBrazil.do?id=15. Accessed February 28, 2013.

2010. "IBSA Academic Forum". Available at: http://www.ipcundp.org/ipc/HomeIBSA.do. Accessed February 28, 2013.

. 2012a. "The Social Policy Brand in the South: The Consolidation of IPC-IG's Social Protection Portfolio". Available at: http://de.slideshare.net/ipcig/social-protection-ipc-igpresentationitamaraty\#btnPrevious. Accessed February 28, 2013.

2012b. "Strengthening the Voices of the Global South on Development". Available at: http://de.slideshare.net/ipcig/inclusivegrowth-the-voices-of-the-south-on-development. Accessed February 28, 2013.

International Poverty Centre - IPC. 2008. "Brazil \& Africa Newsletter". Available at: http://www.ipc-undp.org/pub/IPCNewsletter1.pdf. Accessed February 28, 2013.

Marco Estratégico. s.d.. "Fondo de Cooperación Técnica Brasil-FAO. Marco Estratégico para la Acción". Available at: http://www.fao.org/alc/file/media/proy/p_brasil/me_programa_brasil. pdf. Accessed October 10, 2013.

Memorandum of Understanding between UNDP and the Brazilian government. 2009. Available at:

http://www.ipc-undp.org/pressroom/files/ipc103.pdf. Accessed February 28, 2013.

MDS. 2008. "The Brazilian Social Protection Policies and Experience, and the Developing South to South Cooperation". Available at: http://www.ipc-undp.org/doc_africa_brazil/BRAZIL-MDS.pdf.

Accessed February 28, 2013.

Ministério de Relações Exteriores - MRE. 2002. "Criação do Centro Internacional para Políticas de Redução da Pobreza (Acordo entre o Programa das Nações Unidas para Desenvolvimento - PNUD e o Governo Brasileiro)", Nota $\mathrm{N}^{\circ}$ 197. Available at: 
http://kitplone.itamaraty.gov.br/sala-de-imprensa/notas-aimprensa/2002/02/criacao-do-centro-internacional-para-politicas-de.

Accessed February 28, 2013.

. 2008. "Fundo da Agricultura Familiar (FAF) do Mercosul", CMC 45/08. Available at: http://dai-mre.serpro.gov.br/atosinternacionais/multilaterais/fundo-da-agricultura-familiar-faf-domercosul-dec-cmc-no-45-08/. Accessed March 05, 2013. . 2010. "Fundo IBAS recebe o prêmio "Millennium Development Goals' IBSA Fund receives 'Millennium Development Goals' Award", 21 de setembro. Available at: http://www.itamaraty.gov.br/sala-deimprensa/notas-a-imprensa/fundo-ibas-recebe-o-premio-

201 cmillennium-development-goals201d. Accessed May 03, 2012.

Portal Brasil. 2010. "Think-Tank Seminar to discuss BRIC role in the postcrisis". Available at:

http://www.brasil.gov.br/news/history/2010/04/14/think-tankseminar-to-discuss-bric-role-in-the-postcrisis/newsitem_view?set_language=en. Accessed February 27, 2013.

REAF. 2008a. "Histórico". Available at: http://www.reafmercosul.org/reaf/sobre/historico. Accessed March 05, 2013.

2008b. "Consolidação da REAF". Available at: http://www.reafmercosul.org/reaf/sobre/consolidacaoreaf. Accessed March 05, 2013.

Savanachi, Eduardo. 2010. "Entrevista". Dinheiro Rural 73. Available at: http://revistadinheirorural.terra.com.br/secao/entrevista/193814entrevista. Accessed March 07, 2013.

SICA. 2005. "Reunión de los Jefes de Estado y de Gobierno del Sistema de la Integración Centroamericana y la República Federativa de Brasil", 13 de setembro. Available at: http://www.sieca.int/site/VisorDocs.aspx?IDDOC=Cache/1799000000 0984/17990000000984.swf. Accessed March 06, 2013.

Souza, Darana; e Israel Klug. 2012. "A Multidimensional Approach to Food Security: PAA Africa". Poverty in Focus - The Role of South-South Cooperation in Inclusive and Sustainable Agricultural Development 24: 16-18.

UN Brazil. 2011. "Brasil e Programa Mundial de Alimentos inauguram Centro de Excelência Contra a Fome", 07 de novembro. Available at: http://www.onu.org.br/brasil-e-programa-mundial-de-alimentosinauguram-centro-de-excelencia-contra-a-fome/. Accessed March 20, 2012. 
UNDP. 2012. "Rio+20 Legacy: World Centre for Sustainable Development launched by Brazil and UNDP". Available at: http://www.undp.org/content/undp/en/home/presscenter/pressreleases/ 2012/06/22/rio-20-legacy-world-centre-for-sustainable-developmentlaunched-by-brazil-and-undp-.html. Accessed February 28, 2013.

WFP. 2011. "Brazil and WFP launch The Centre of Excellence Against Hunger", 07 de novembro. Available at: http://www.wfp.org/news/news-release/brazil-and-wfp-launch-centreexcellence-against-hunger. Accessed April 27, 2013. . 2013. "Centro de Excelência contra a Fome: Relatório Annual 2012", Available at: http://www.wfp.org/content/relat\%C3\%B3rio-anual2012-do-centro-de-excel\%C3\%AAncia. Accessed March 04, 2013. 


\begin{abstract}
Brazil's Zero Hunger Strategy is nowadays regarded as an international model in the global fight against hunger and poverty. I will analyse the mechanisms Brazil created to allow other governments and international organisations to benefit from the experience Brazil collected in the Zero Hunger Strategy. Based on the theoretical concept of "nodal governance" I will describe four of these global governance mechanisms (the International Policy Centre for Inclusive Growth, the WFP Centre of Excellence Against Hunger, the IBSA Trust Fund and the FAO-Brazil Trust Fund) as essential nodes which helped to 1) strengthen Brazil's exercise of influence in its international fight against hunger and poverty and 2) reinforced the global governance of food security. This analysis demonstrates how Brazil has been able to raise its profile as a leader in fighting hunger and poverty in the global South.
\end{abstract}

\title{
KEYWORDS
}

Brazil; Global Governance; Global South. 